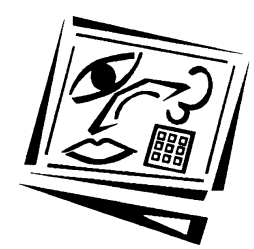

\title{
Collegial mentoring for effective whole school professional development in the use of IWB technologies
}

\author{
Anthony Jones and John Vincent
} The University of Melbourne

\begin{abstract}
The focus of this chapter is the provision of teacher professional development as needed - just in time. The specific context is the application of peer mentoring in teaching and learning with interactive whiteboards. Data was gathered from two research projects that investigated aspects of teachers mentoring colleagues in Australia. In both projects lessons were video recorded and the teachers interviewed about their perceptions of ICT use in the lessons. In one project two teachers were appointed as half-time mentors to assist colleagues in classroom use of IWBs. This appeared to result in improved levels of success for all the stakeholders. The aim in the other project was to explore how to prepare primary classroom teachers to become mentors within their school. One recommendation arising from the research is that education systems should fund ICT mentor positions to help overcome immediate teacher needs as quickly as possible.
\end{abstract}

\section{Introduction}

In many countries concerns about school use of ICT have shifted from the provision of technological hardware to the methods for improving the knowledge and skills of teachers (Kennewell \& Higgins, 2007). As more educational applications of ICT become available to schools, teachers face ongoing pressure to put into practice new teaching techniques and pedagogical strategies. However, there is evidence from research and benchmark data indicating that in general ICT applications are not providing education systems, teachers and students with the educational benefits that were expected Hennessy, Deaney, Ruthven \& Winterbottom, 2007). One reported reason is because teachers lack access to appropriate resource material and professional development (Becta, 2003; Measday, 2005). There appears to be little systematic continuing professional development that links the use of interactive whiteboards with improving teaching and learning, especially in core subjects including English, mathematics and science.

This article reports on teachers changing their pedagogic practices following the simultaneous acquisition of IWBs and the introduction of a system of professional development based around the use of peer mentoring to support teachers. In this context mentoring is concerned with the ability to "facilitate, guide, and encourage continuous innovation, learning, and growth to prepare for the future (Johnson, 1997, p.13). A brief summary of relevant research suggests that the role in mentoring needs to be systematic and planned so that the mentoring experience is beneficial and productive for both mentee and mentor (Daresh, 2001; Hay, 1995; Johnson, 1997). Throughout this paper peer mentoring will refer to both the mentor and the mentee as teachers from the same school, i.e. colleagues. 
To complement the reporting in this article, a brief review of relevant literature and then the methodology used to collect and analyse the data is described. Results from this analysis, supported by excerpts from interviews with participants, are used to discuss the role of collegial mentoring in helping develop a collaborative network for sharing IWB-related experiences, techniques, and resources.

\section{Relevant literature in the field}

Research into teaching, learning and IWBs has proliferated in recent years. Undoubtedly one reason for this has been the ever-increasing number of IWBs installed in school classrooms (BESA, 2006 as cited in Kennewell \& Higgins, 2007). A summary of some of this research follows in two parts - first, classroom use and then a consideration of analysis techniques that have been applied.

\section{Classroom use of IWBs}

There have been many claims made about the potential of ICT in general to improve teaching and learning (Hennessy et al., 2007). In particular, among the claims made for IWB use are greater interactivity between teachers and students, and increased pupil engagement, motivation and enjoyment, all potentially leading to improvements in pupil attainments (Hall \& Higgins, 2005). A review of research on the introduction of IWBs in UK classrooms (Smith, Higgins, Wall \& Miller, 2005) revealed a clear preference for their use by both teachers and pupils. This had been noted previously by Cogill (2002), who stated that all the teachers in her study were enthusiastic about the tools this new technology offered to help structure their lessons, to save time scribing, to attract and retain children's attention and to provide large attractive text and images.

While investigating how teachers integrated what ICT was available, into their teaching, we became aware of shortcomings in the theoretical underpinnings of models and techniques being employed to analyse and describe pedagogical strategies used in the classroom with ICT. In particular, it was considered that there was a tendency to ignore teaching proficiency by emphasising ICT-related technical skills, and also to categorise the analysis through terms that could be interpreted as value judgements by the researchers about the teachers.

Historical records contain a variety of descriptions of different approaches to teaching and learning (Jones, McDougall \& Murnane, 2004). In general such examples have tended to focus on learning rather than teaching. However, over the past century, issues relating to teaching have become more prominent. More recently, classroom interactions relating to teaching and learning have become almost mandated as $I R F$, a three stage process whereby a teacher 'initiates' something, for example asks a question or poses a problem, then a student or students 'respond', and finally there is some type of teacher controlled follow up or 'feedback'.

Among the video-recorded lesson data we have collected and analysed there are many instances of the IRF model being used across the curriculum and at any grade level, and both in lessons where there is no use of any learning technology as well as in lessons with a high level of IWB use. IRFD is an extension of this model that includes opportunity for class 'discussion' following the teacher feedback. 
A considerable amount of material, both anecdotal and research based, has been published about continuing professional development (CPD) for classroom teachers (Becta, 2004). Because classroom use of ICT is a relatively recent phenomenon, the body of research evidence concerning professional development for teaching and learning with ICT is not vast, however, it is increasing in both quantity and quality. It is noted in the Becta (2004) report that because there are so many differences between CPD offerings, for example focussing on either a single subject or topic or on a specific piece of software or hardware, it is not possible to make meaningful comparisons. In addition, the quality of the CPD and the measurement of consequential changes to the behaviour of teachers and learners are critical factors in determining CPD effectiveness (Becta, 2004, p. 3).

\section{Instruments used for studying teacher interaction with an IWB}

The analytical approach adopted in this article has been informed by a variety of models and methods of analysis including the Computer Based Adoption Model (Hall \& Higgins, 1987; Hooper \& Rieber,1995; Beauchamp, 2004; Tanner, Jones, Kennewell \& Beauchamp, 2005; and Fisher, Higgins \& Loveless, 2006). However, as noted earlier, we were concerned about the apparent focus on skills and the use of value laden descriptive terminology in some of these models. Two frameworks, those of the TIMMS study (Clarke, 2006) and Beauchamp's (2004) transition framework proved to be the most useful in providing a new tool which has been called a Hierarchy of Pedagogical Strategies (HoPS) (Vincent \& Jones, 2007) (see Appendix). The HoPS borrows Beauchamp's 'substitutional' and 'synergistic' categories as the outer extremes of a range of styles, but introduces other headings (experimental, interactional) that reduce the judgmental nature of labels. The actual instrument examines ICT usage and management as well as teachers' skills. On its own it is too cumbersome to incorporate pedagogical strategies such as questioning, task making and student action all into the one framework. Consequently, a second instrument was developed based on Bernstein's (1990) pedagogical framing concepts. This framing model adopts Bernstein's concept of teaching strategies that range from highly controlled ('strongly framed') to ones that closely involve the students ('weakly framed'), with intermediate framing levels in between. The model interprets some of Bernstein's criteria to create a rubric through which to test the framing strength of lessons. There are similarities to the Tanner et al. (2005) interactivity model, but the framing model deals not only with obvious interactivity, but also with teacher task making, teacher questioning, and student actions.

Research is needed to collect empirical evidence so that the processes of teaching and learning with this new technology are more fully understood (Cogill, 2002; Smith et al., 2005; Sweeney, 2006). In their review, Smith et al. (2005) were not able to identify any rigorous studies describing the impact of IWB use on learners' attainment or documenting actual changes in classroom interaction. While the use of an IWB to encourage an interactive environment where pupils actively participate in the social construction of knowledge is sometimes presented as a means to transform education, it is clear from the literature that to date this does not always occur (Hennessy et al., 2007; Higgins, Beauchamp \& Miller, 2007). In the context of widespread acquisition of IWBs in Australian schools, the present study addresses these gaps in research and practice. 


\section{Research methodology}

The research that informs much of this article occurred throughout 2007 and 2008 in schools in the Australian state of Victoria. The largest study involved all sixty teachers from a rural secondary college with approximately 850 students. The school had placed IWBs in strategic locations, but was not able to put one in each classroom. The IWB supplier had provided introductory professional development for all teachers, and a more advanced session based on the Easiteach software for a smaller group of interested teachers. All of the teachers agreed to lessons being video-recorded if they were using an IWB when the researchers were in the school. Towards the end of the 2007 school year the Principal advertised a full time position for a mentor in the classroom use of IWBs. A final solution was achieved when the school leadership team decided to appoint two teachers with half-time mentor positions. This meant that the two teachers could continue to teach their senior classes as well as have time to locate and develop IWB resources and mentor colleagues.

Throughout the whole school year, teachers, students and mentors were observed, recorded and interviewed. The mentors and some of the teachers were observed, video recorded and interviewed several times. Videos of recorded lessons were used as a stimulus in some of the interviews. Prior to analysing interview data the interviews were transcribed and returned to the interviewee for checking. Researchers read through each interview and used different colours to highlight particular terminology or ideas. From this process a range of categories were developed to assist in encoding the data, and the results were transferred to a matrix for analysis (Miles \& Huberman, 1994).

In addition to this year-long study, a number of smaller studies were conducted in primary schools, investigating how best to prepare classroom teachers to become effective IWB mentors to colleagues. All the teachers involved in these primary school studies were part time researchers as they carried out their normal teaching and administrative duties as well as the research. All of these research projects used a novel system for video data collection and analysis that enabled case study-like approaches to be used in investigations of the complex interactions taking place in classrooms. This method was pioneered by Clarke and his colleagues at the International Centre for Classroom Research (ICCR) (Clarke, Keitel \& Shimizu, 2006) for use in studies of mathematics teaching. Using the ICCR multi-camera video recording and analysis software to obtain rich, detailed data on classroom interactions in lessons in which IWBs were used, enable the projects discussed here to study students' learning as well as classroom teaching in a range of curriculum areas.

Data collection for the studies included focus group discussions and interviews with teachers and students, multi-camera video recording and analysis of class lessons, administration of questionnaires, and field notes made by researchers. These methods are summarised in Table 1.

Wegerif et al. (1998) investigated learning resulting from the classroom use of two software programs they designed in accordance with their guidelines. In contrast with control groups, the discussions they observed in classrooms using their software exhibited a number of characteristic features; from these they developed a list of types of classroom interactions likely to assist and promote learning: 
- students asking each other task-focused questions;

- the giving of reasons for statements and challenges;

- consideration of more than one possible position;

- drawing of opinions from all group members;

- students reaching agreement before taking action.

Table 1: Data collection strategies and methods used in the research projects.

\begin{tabular}{|l|l|}
\hline \multicolumn{1}{|c|}{ Aim } & \multicolumn{1}{|c|}{ Data collection strategies and methods } \\
\hline $\begin{array}{l}\text { Development of Wegerif's theoretical } \\
\text { framework and guidelines for software } \\
\text { selection, teacher support and professional } \\
\text { development. }\end{array}$ & $\begin{array}{l}\text { Focus group discussions and comprehensive } \\
\text { analysis of all the teacher, student and } \\
\text { classroom data. }\end{array}$ \\
\hline $\begin{array}{l}\text { Selection of software for use with IWBs to } \\
\text { support classroom discussion and enhance } \\
\text { collaboration and teamwork skills. }\end{array}$ & $\begin{array}{l}\text { Survey of available software. } \\
\text { Teacher meeting to consider software types to } \\
\text { encourage classroom interaction. }\end{array}$ \\
\hline $\begin{array}{l}\text { Investigation of classroom practices and } \\
\text { pedagogical strategies for collaborative } \\
\text { learning. }\end{array}$ & $\begin{array}{l}\text { Teacher focus group to examine Wegerif's idea } \\
\text { of exploratory talk, and pedagogical strategies } \\
\text { using IWB to promote discussion and } \\
\text { collaboration, and to chose lesson events to be } \\
\text { marked for analysis. } \\
\text { Video recording of lessons. }\end{array}$ \\
\hline $\begin{array}{l}\text { Development of taxonomy of classroom } \\
\text { activities and teaching strategies for enhancing } \\
\text { collaboration. }\end{array}$ & $\begin{array}{l}\text { Focus group discussions to reflect on activities } \\
\text { and pedagogical strategies used; analysis of } \\
\text { video-recorded lessons; post-lesson video- } \\
\text { simulated interviews with teachers. }\end{array}$ \\
\hline $\begin{array}{l}\text { Investigation of approaches to measurement of } \\
\text { collaborative skills. }\end{array}$ & $\begin{array}{l}\text { Teacher observations and interviews; } \\
\text { Student questionnaires on collaboration; } \\
\text { Focus group discussions consider these. }\end{array}$ \\
\hline
\end{tabular}

In the studies discussed here these features of classroom interaction were used as guides, and modified as appropriate for secondary or primary level students. They then formed the basis of teacher focus group discussions of the use of IWBs in order to facilitate classroom interaction and collaborative problem solving.

\section{Video recording of lessons}

Several approaches to video recording lessons have been experimented with in these projects. Initially three cameras were used to record lessons in which IWBs and other ICT was used. One camera recorded the actions and utterances of the teacher as s/he moved around the room, wearing a wireless microphone. The second camera was set up in a corner of the room to provide a panoramic view, with the aim of enabling researchers to see what students were doing, especially when the teacher was in another part of the room. A third camera was focused on a pre-selected group of students as they worked and their discussions were recorded using separate microphones.

To assist post lesson analysis, images were superimposed on each other, depending on what the specific focus of investigation was. One image (providing the primary source of data) was arranged to occupy the whole screen, and a window was superimposed at the top left corner of the screen to show the view from another camera. Images from the third camera could be combined with either of the others. Procedures developed at the International Centre for Classroom Research at Melbourne University were used for compression, editing, storage and transfer of digitised video data (Clarke, Keitel \& 
Shimizu, 2006). The researchers received a split-screen video record of each lesson on a DVD, and lessons were initially analysed by creating a log of lesson events and associated times. During observed lessons a researcher made field notes and recorded lesson events in a prepared matrix. Video data of lessons was analysed to provide highly detailed categorisation and understanding of classroom interactions. In particular, lessons were analysed for lesson events and pedagogic strategies employed by teachers.

\section{Teacher professional development for effective IWB use}

While teacher training by IWB suppliers provides skills that might enable teachers to use the hardware and software, this has not been found to provide pedagogical knowledge for integrating IWBs into the curriculum and the classroom (Beauchamp, 2004). It is reported by Smith et al. (2005) that teachers need sustained and individual guidance on a 'need to know' basis or as part of more structured continuing support. The studies reported here commenced after teachers had completed some training provided by the IWB supplier, and investigated a range of ongoing, school-based support and professional development strategies.

\section{Just in time: Professional development when needed}

Many education systems mandate continuing professional development for their teachers. However, while this has undoubted merit, too often the specific requirements for the professional development emphasise the amount of time that teachers are expected to be involved in, rather than either the content or style. It is most unusual for an education system to specify a particular approach to the professional development process, such as mentoring. It is probable that some approaches to professional development are more effective than others at particular stages of a teacher's development. Much of the published literature on mentoring in education concentrates on the general mentoring of beginning teachers about school policies and practices (Feiman-Nemser, 2006; Johnson, 1997). In this context it is usual for an experienced and knowledgeable teacher to mentor the beginning teacher. However, this article looks at collegial mentoring in a specific aspect of classroom ICT use, where it is quite possible that the mentee is the more experienced teacher or ICT user.

When education systems mandate a certain amount of teacher professional development to be taken over a set period of time, there is usually the requirement that teachers undertake the equivalent to three full days of professional development during a school semester. While this model might facilitate long-term planning for CPD and coincide with Johnson's (1997) belief that mentoring is a preparation for the future, the model is not relevant when issues arise at the teaching coalface.

It has been suggested that in teaching (in contrast to business and other endeavours), effective mentoring rarely comes from outside the organisation (Feiman-Nemser, 2006). Teachers seem to resist externally sourced expert mentors. Peer mentoring on the other hand is effective under some circumstances. Feiman-Nemser (2006) also argues that the major problem of mentoring in education is that the very existence of a mentor implies an inequality or hierarchy of expertise. Teachers are notoriously defensive about admitting to not knowing. However, in the case of a new technology being introduced for the first time into a school, the technology is new to everyone, there are few outside the organisation who are able to bring expertise, and there are no 
internal 'old' views about the specific technology. Hence the peer mentors are learning alongside the mentees as a joint exploration.

To enable potential affordances of the IWB, or any other new digital technology, to become a reality in classroom teaching and learning, it is essential to provide teachers appropriate and timely opportunities for professional learning. According to Fisher, Higgins and Loveless (2006), teachers are more amenable to effective professional development when the following conditions are met:

- the aims and purpose of activities are relevant and authentic to their own lives;

- they can use a variety of tools to help them realise and express their goals;

- they are in a relationship with others in the wider community which shares rules and ways of working.

\section{Internal versus external CPD}

This and the following sections contain excerpts of interviews between one of the authors (R) and the two teacher mentors (M and B) from a Rural Secondary College (RSC).

Teachers have reported mixed feelings and experiences about CPD undertaken and organised by people outside their school. During an interview with the two mentors at RSC it was noted that:

... the PD model I have gone through for the greater part of my teaching career is that you have to go outside the school (B);

Whereas had we disappeared and gone for a week to do something, we'd have come back and stayed in our own little closet. It may not have been shared perhaps to the degree it is (M).

Both these experienced teachers saw problems with non school-based CPD. In particular they commented on the sharing aspect, ways in which knowledge gained by some teachers can be shared with colleagues:

We are learning together by the seat of our pants. So it stays with us and is spreading' (M);

I think this [mentoring] recognises that within a school there is a wide range of people with a wide range of skills, so if you can harness a way to share those skills amongst your staff not only is it more efficient, a lot cheaper, it's also very powerful' (B).

\section{Trust}

The mentors believed that over the year high levels of trust had been developed in two areas - first between the school leadership group and the mentors, and also between the mentors and other teachers. To illustrate with an extract from an interview with the two mentors:

R: $\quad$ Does that mean it [mentoring] has changed your relationship with the hierarchy of the school?

M: It has taken us a little while to realise that we can do things. We were told we could do whatever we wanted to do.

B: $\quad$ Yes, it was made clear that the Principal was putting his trust in us, and he wanted us to run with the position and do what we thought we should do 
with it, not to be running backwards and forwards, and as such the job description was holistic but it wasn't specific.

$\mathrm{R}: \quad$ So is that element of trust a crucial part of the mentoring process?

M/B: I'd say so, yes!

B: $\quad$ So we don't feel we've got to be on his [Principal] door all the time telling him what we are doing.

\section{Mentoring analyses}

In the secondary school study at RSC, mentoring was undertaken by peer teachers, and some mentoring sessions were filmed to observe the process of peer mentoring and to seek an understanding of the dynamics that were present. It was hoped that analysis of these mentoring episodes would give an insight into dynamics that were at work as mentees sought to absorb the affordances of the technology into their pedagogical schema.

From the literature it was expected that mentoring would be largely a one to one information sharing time, with the mentor, as 'expert' offering most of the information and occupying most of the time. A time analysis of these sessions was undertaken to examine the time-information relationships (see Table 2).

Table 2: Mentor time-information relationships

\begin{tabular}{|c|c|c|}
\hline Action & $\begin{array}{l}\% \text { of mentoring } \\
\text { sessions }\end{array}$ & Comment \\
\hline $\begin{array}{l}\text { Mentees talking or demonstrating } \\
\text { needs. }\end{array}$ & $54 \%$ & $\begin{array}{l}\text { Mentor largely listening to mentee with } \\
\text { occasional clarification interjections. }\end{array}$ \\
\hline $\begin{array}{l}\text { Mentor technology or software skill } \\
\text { development. }\end{array}$ & $28 \%$ & Direct demonstration or tutoring. \\
\hline Teaching hints by mentor. & $11 \%$ & Usually relating to needs expressed. \\
\hline $\begin{array}{l}\text { Mentor searching for answers or } \\
\text { offering 'to find out'. }\end{array}$ & $7 \%$ & $\begin{array}{l}\text { Mentors frequently prepared to admit } \\
\text { lack of knowledge. }\end{array}$ \\
\hline
\end{tabular}

Each mentored teacher was subsequently video recorded and interviewed using the video as a stimulus. It was apparent that the mentees were very comfortable with the process, admitted a lack of knowledge to the non-expert peers, and were also at ease with receiving teaching suggestions. This was confirmed in interviews with the teachers. The mentees also talked about the supportive atmosphere created by this type of mentoring, and were thus happy for the mentors to team teach with them for their first few uses of the technology. Teachers in interviews and surveys constantly referred to the support system which took the fear of the technology and its unexpected consequences out of the classroom. But, as Vincent and Jones (2008) reported, what the researchers also observed was that the two mentors rapidly assumed that flexible uses and attitudes to pedagogic strategies were as important as skills, and integrated those attitudes into their work with teachers. Understandably, the teachers were reluctant in interview to admit this as it might have given the impression that their standard teaching approach was too rigid.

In the studies in primary schools, the luxury of teacher release did not exist on the scale of the secondary school, but from the observations made in the secondary study, the researchers attempted to emulate the methods described, and to mentor new users of the IWB technology as though they were peers. In the case of a study in an early 
years classroom (Vincent 2007), although the mentor was also a research assistant, she was a classroom teacher with a wide experience of early years teaching and assumed the role of a peer mentor while filming the teacher. Early in the project, the mentee (called Sue) resisted any change to her style and became more didactic and strongly framed. One afternoon, Sue allowed her mentor to team-teach with her and she relaxed to allow the children to create ideas and writing on the board. That proved to be a turning point because Sue discovered that the children became more attentive, more inventive and enthusiastic as she weakened the framing. Vincent \& Jones (2007) report that in interview, Sue admitted that as a result of the mentoring experience with the IWB she had changed her view of her relationship with the class from that with a 'teacher' mentality to one more concerned with the 'team'. The following exchange exemplifies this:

Interviewer: You've talked about how you suddenly realised the children could take
over and so on. Has that changed their relationship with you?
Sue:
It's probably let them gain a little bit more respect I suppose, knowing
that teachers don't know everything. You know, knowing 'well we are
students but we can come to school to help our teacher out. We're not just
here to sit and listen. We're actually part of this class. We're here to help
[the teacher] out as well'.
poes that relate to all the children? Or are there certain children that it
Norterly relates to?
No, I found it with all of them. But even more so with the children that
often wouldn't put their hands up. The children that were even
sometimes disruptive. They were even more eager to assist with the
problem solving and in turn they would sit still for a longer period of
time. Their attention was focused in a particular area or in a responsible
way. They were just more engaged. Maybe they even felt a bit more
important. Maybe even a bit more grown up. You know how sometimes
kids get that image of the teacher, well that's the teacher and you sit and
you listen, we're the kids. It's more of a team. You're working as a team
to create a page or to create an idea and to work through any problems.
It's not so much of a hierarchy.

In another primary school, the researchers offered free professional learning sessions to the school, which had approached the University for help with IWBs. The researchers then invited teachers to volunteer to be mentored and filmed, to experiment with building mentoring expertise by the mentees. The voluntary nature ensured that the two teachers who elected to participate were willing recruits. The researchers then sought to build the same atmosphere of trust and support seen as effective in the secondary setting, and were rewarded with very strong evidence of a change in teaching style towards 'weak framed' with strong pupil involvement.

\section{Pedagogical changes}

The core of the studies on the IWB technologies revealed a pedagogical impact on the teachers. To observe and analyse pedagogical changes, the studies have used the two instruments described earlier, one based on Beauchamp's transitional framework (2004) and the other constructed from Bernstein's work on pedagogical framing (1990).

Vincent and Jones (2008) conducted an analysis of the lessons in the secondary study by taking each lesson event and placing the teaching actions within the scales of both instruments. Figures 1 and 2 show two examples taken from that study. 


\begin{tabular}{|c|c|c|c|c|}
\hline \multirow{2}{*}{ Time } & \multicolumn{3}{|c|}{$\begin{array}{c}\text { Framing strength } \\
(1=\text { strong, } 5=\text { weak })\end{array}$} & \multirow{2}{*}{ Lesson event } \\
\hline & $\begin{array}{c}\text { Task } \\
\text { making }\end{array}$ & Questions & $\begin{array}{c}\text { Student } \\
\text { action }\end{array}$ & \\
\hline 00:00 & 1 & 1 & 1 & $\begin{array}{l}\text { Defines task (decimal recognition). } \\
\text { Revises decimal matching with fractions from self- } \\
\text { prepared set of slides. } \\
\text { Specifies activities. }\end{array}$ \\
\hline $06: 20$ & 1 & 1 & 1 & Uploaded decimal recognition game. \\
\hline 07:54 & 1 & 1 & 1 & $\begin{array}{l}\text { Appoints students to respond to matching pairs. Poses } \\
\text { closed questions. }\end{array}$ \\
\hline $18: 36$ & 1 & 1 & 1 & Sets paper tasks, insists on uniform presentation. \\
\hline $28: 36$ & 1 & 1 & 1 & $\begin{array}{l}\text { Defines new task (BOMDAS). Use a self-prepared } \\
\text { visual slide set to revise order of operations. Questions } \\
\text { and responses closed. }\end{array}$ \\
\hline 31:02 & 1 & 1 & 1 & $\begin{array}{l}\text { Introduces and activates an order of operations quiz } \\
\text { game (uploaded) in which teacher controls the game } \\
\text { (and uses the possible interactions herself) while the } \\
\text { students write answers on paper. }\end{array}$ \\
\hline
\end{tabular}

Figure 1: Framing analysis Esther, Year 8 mathematics

\begin{tabular}{|c|c|c|c|c|}
\hline \multirow[b]{2}{*}{ Time } & \multicolumn{3}{|c|}{ Elements of practice } & \multirow[b]{2}{*}{ Lesson event } \\
\hline & Teacher skills & ICT usage & $\begin{array}{c}\text { Classroom } \\
\text { management }\end{array}$ & \\
\hline 00:00 & $\begin{array}{l}\text { Interactional } \\
\text { (stored } \\
\text { prepared } \\
\text { materials) }\end{array}$ & Experimental & Substitutional & $\begin{array}{l}\text { Defines task (decimal recognition). } \\
\text { Revises decimal matching with fractions } \\
\text { from self-prepared set of slides. } \\
\text { Specifies activities. }\end{array}$ \\
\hline 06:20 & & & & Uploaded decimal recognition game. \\
\hline 07:54 & Experimental & Experimental & Substitutional & $\begin{array}{l}\text { Appoints students to respond to matching } \\
\text { pairs. Poses closed questions. }\end{array}$ \\
\hline $18: 36$ & & & & $\begin{array}{l}\text { Sets paper tasks, insists on uniform } \\
\text { presentation. }\end{array}$ \\
\hline $28: 36$ & $\begin{array}{l}\text { Interactional } \\
\text { (stored self- } \\
\text { prepared } \\
\text { material) }\end{array}$ & Interactional & Substitutional & $\begin{array}{l}\text { Defines new task (BODMAS). Use a self- } \\
\text { prepared visual slide set to revise order of } \\
\text { operations. Questions and responses } \\
\text { closed. }\end{array}$ \\
\hline $31: 02$ & Experimental & Experimental & Substitutional & $\begin{array}{l}\text { Introduces and activates an order of } \\
\text { operations quiz game (uploaded) in which } \\
\text { teacher controls the game (and uses the } \\
\text { possible interactions herself) while the } \\
\text { students write answers on paper. }\end{array}$ \\
\hline
\end{tabular}

Figure 2: HoPS analysis Esther, Year 8 mathematics

In these studies, of those teachers observed teaching, few lessons using the boards displayed common characteristics on both instruments. An example of this disparity is 'Esther', a mathematics teacher. Esther received mentoring for preparation of a mathematics lesson on decimals and order of operations with a Year 8 class, and by using the framing model, which only considers pedagogical strategies rather than skills, it was observed that Esther remained very clearly at level 1 ('strong framing') throughout for all three criteria (teacher controlled tasks, closed questions and student action). When the HoPs model was used instead, as expected her classroom management remained substitutional because she used the IWB as a substitute for a standard white or black board. Teacher presentation was dominant throughout. 
However, the HoPS showed that for Teacher skills and ICT usage Esther presented as a teacher willing to develop pre-prepared files, to use other stored resources and to explore some of the multimedia tools that the IWBs and their software can offer, even though her management style did not stray from didactic and substitutional. It would be very easy to make a value judgment about the IWB's adaptation to Esther's didactic teaching style without this extra information that the HoPS analysis gives us. Using affordances newly available in the IWB and its software, Esther felt (in interview) that it had enhanced her preparation and delivery of the lesson and that the mentoring had enabled this to happen.

Further evidence of the value of the two instruments and the impact of the mentoring at the secondary school came from multiple filming of Debbie. Early in her usage of the board, Debbie taught part of a LOTE Indonesian lesson on the topic of time. The lesson was captured on video. Its framing analysis (Figure 3) shows that for most of this part of the lesson her pedagogical framing was very strong, weakening towards the end as she began to open the questioning and allow some students to experiment with a drawing idea on the board.

\begin{tabular}{|c|c|c|c|c|}
\hline \multirow{2}{*}{ Time } & \multicolumn{3}{|c|}{$\begin{array}{c}\text { Framing strength } \\
(1=\text { strong, } 5=\text { weak })\end{array}$} & \multirow{2}{*}{ Lesson event } \\
\hline & $\begin{array}{c}\text { Task } \\
\text { making }\end{array}$ & Questions & $\begin{array}{l}\text { Student } \\
\text { action }\end{array}$ & \\
\hline 00:00 & 1 & 1 & 1 & $\begin{array}{l}\text { Defines time task (matching). } \\
\text { Does not accept floor comments and question. }\end{array}$ \\
\hline $04: 34$ & 1 & 1 & 1 & $\begin{array}{l}\text { Uploaded train times games: interactive response through } \\
\text { IWB. }\end{array}$ \\
\hline 10.53 & $\begin{array}{l}1 \\
2\end{array}$ & 2 & 1 & $\begin{array}{l}\text { Matching quarter hour statements with clocks: board } \\
\text { manipulation. Allows student to correct teacher error. }\end{array}$ \\
\hline 18:21 & 1 & 1 & 1 & Time matching through IWB, wholly controlled. \\
\hline 20:36 & 2 & 3 & 2 & $\begin{array}{l}\text { Matching time task. } \\
\text { Questions open ("Tell me what is going through your } \\
\text { mind as you think about it") although final task is closed. }\end{array}$ \\
\hline $23: 05$ & 3 & 3 & 2 & $\begin{array}{l}\text { Matching time and words with arrows. Introduces making } \\
\text { arrows, and suggests student chooses a question and } \\
\text { arrow style. Students given some choice of action and } \\
\text { establishment of criteria. }\end{array}$ \\
\hline
\end{tabular}

Figure 3: Framing analysis, Debbie, Year 8 Indonesian LOTE lesson.

By using the HoPS analysis (Figure 4) to overlay meaning onto the pedagogical strategies there is a deeper understanding of the teacher's use of the technology. HoPs shows a considerable use of experimental and interactional ICT skills and usage. By the HoPS definitions for classroom management, the analysis shows that this aspect was not wholly at the substitutional level. At the start of the lesson, for example, all interactions were at the direction of the teacher, and no variation to the plan was allowed, making this strongly framed in the Framing analysis, but Debbie did allow students to come to the board and operate it under her direction, an experimental level in the HoPS instrument. Later, this developed into interactional management.

This teacher had just participated in a mentoring session before she was filmed, and the mentor was present to support her at the start. The mentor reported that the mentoring session had involved a great deal of 'this is what I want to do, how do I do it?' type questions, but Debbie told the interviewer that the key support given was 
confidence. Debbie is shown as strongly framing her pedagogy for much of the LOTE lesson, HoPS reveals experimental use of ICT skills and usage, and sometimes beyond that to interactional use (involving the students). Later in the lesson, she continues to use these techniques, but the framing instrument indicates she weakens the framework and begins to use open questions and accept open answers. Thus each instrument has given additional information about the ways that the technology is interacting with the teaching. Later in the year, Debbie changed to a very devolved strategy with the IWB, teaching her class to write material for the board with the software, and using the school computers for a set task where the students created a multimodal interactive conversation that had to be conducted in Indonesian. By this time she had cut herself completely clear of the mentoring, although always sharing experiences with both mentors.

\begin{tabular}{|c|c|c|c|c|}
\hline \multirow[b]{2}{*}{ Time } & \multicolumn{3}{|c|}{ Elements of practice } & \multirow[b]{2}{*}{ Lesson event } \\
\hline & $\begin{array}{l}\text { Teacher } \\
\text { skills }\end{array}$ & $\begin{array}{c}\text { ICT } \\
\text { usage }\end{array}$ & $\begin{array}{c}\text { Classroom } \\
\text { management }\end{array}$ & \\
\hline 00:00 & $\begin{array}{l}\text { Interactional } \\
\text { (stored pre- } \\
\text { prepared } \\
\text { activities) }\end{array}$ & Interactional & $\begin{array}{l}\text { Experimental } \\
\text { (students use } \\
\text { board under } \\
\text { direction) }\end{array}$ & $\begin{array}{l}\text { Defines time task (matching). } \\
\text { Does not accept floor comments and } \\
\text { question. }\end{array}$ \\
\hline 04:34 & $\begin{array}{l}\text { Experimental } \\
\text { (Internet } \\
\text { loaded) }\end{array}$ & Experimental & Experimental & $\begin{array}{l}\text { Uploaded train times games: interactive } \\
\text { response through IWB. }\end{array}$ \\
\hline 10.53 & \begin{tabular}{|l} 
Experimental \\
\\
Interactional
\end{tabular} & Experimental & Experimental & $\begin{array}{l}\text { Matching quarter hour statements with } \\
\text { clocks: board manipulation. Allows student } \\
\text { to correct teacher error. }\end{array}$ \\
\hline $18: 21$ & Experimental & Experimental & Experimental & $\begin{array}{l}\text { Time matching through IWB, wholly } \\
\text { controlled. }\end{array}$ \\
\hline 20:36 & Experimental & Experimental & Interactional & $\begin{array}{l}\text { Matching time task. } \\
\text { Questions open ('Tell me what is going } \\
\text { through your mind as you think about it') } \\
\text { although final task is closed. }\end{array}$ \\
\hline 23:05 & Interactional & \begin{tabular}{|l|} 
Experimental \\
\\
Interactional
\end{tabular} & Interactional & $\begin{array}{l}\text { Matching time and words with arrows. } \\
\text { Introduces making arrows, and suggests } \\
\text { student chooses a question and arrow style. } \\
\text { Students given some choice of action and } \\
\text { establishment of criteria. }\end{array}$ \\
\hline
\end{tabular}

Figure 4: HoPS analysis, Debbie, Year 8 Indonesian LOTE lesson

The use of two instruments for the analysis of the pedagogies employed by teachers has given a greater insight into the changes associated with the technology than the use of a single tool. By accompanying analysis of the teaching strategies with videostimulated interviews, the researchers were able to identify how the use of peer mentoring influenced the changes in both skills and pedagogy as the teachers coped with the new affordances of a previously unknown technology. There were several other important observations that arose from working with both instruments, including:

1. The word 'confidence' kept occurring in interviews, in the sense that the mentors created an atmosphere of confidence within which the teacher could safely experiment. Thus at the secondary school, as teachers matured with their use of the IWB technology they regularly experimented by changing the degree of pupil autonomy and interaction, and hence framing levels, within one lesson. They often 
claimed that this was because they had the support of the mentors whenever they wanted to try something new.

2. HoPS analyses of lessons often revealed that when lesson events occurred that were 'strongly framed', the teachers often expertly used the multimodal affordances of the IWB software such as image manipulation, spotlight tools, image capture, sound video and animation to enhance a section of the lesson that was wholly instructionist. Typically this occurred just after a mentor had discussed a technique that the teacher had not used before. For example, Vincent and Jones (2007) described secondary teacher Nicolas who began an art lesson on PopArt with a multimodal display of art works, spoken commentary and animation devices as he instructed a passive audience about the art genre. In the framing analysis this appeared as 'strongly framed' with a teacher dominated task and closed questions. In the HoPS it appeared as high-level teacher skills and ICT usage. Later in the same lesson, students were invited to use the technology to transform their own photographs into pop-art style pictures, a weakly framed activity handing control to the students. In the subsequent interview, Nicolas talked of working through these techniques sitting next to his mentor, not necessarily interacting directly with her, but to ensure he could achieve his aims. The mentors both claimed that their aim was to ensure that as teachers become aware of the affordances with IWB technologies, they can use them flexibly and differently according to the pedagogical needs of the moment in the lesson. In this study the key to rapid change to making skilful use of the IWB affordances within a weakly framed pedagogy appeared to be the constant support from the two peer mentors.

3. With this kind of peer mentoring a clear pattern developed. Pre-lesson planning led to experimental use of techniques and willingness to accept mentors as team teaching members or safety-net back-up in early lessons. Casting off from the mentors typically came 3-4 lessons later, but this varied with individual confidence.

4. In nearly every case of multiple use following mentoring, the teachers changed their pedagogical stances to weaken their framing. This appeared to relate to a shared attitude to teaching by the mentors, who developed their own philosophy of the role of IWB technologies and shared it with teachers. These changes were able to be recorded and understood through the use of the analysis instruments.

\section{Future research directions}

New educational technologies have always been hard to assimilate into the classroom and the pedagogical repertoires of teachers. While there are always enthusiasts and early adopters, many educational technologies have barely ruffled the surface of teacher practice. Indeed, they have generated such a reaction that has ensured that technologies make little or no difference to teacher practice in the long term. With improved research techniques and with greater understanding of the role of just in time professional learning such as peer mentoring, the moment a new technology with promising affordances appears, it is now possible that it can be successfully integrated in educational practice. Mentoring, especially peer, non-expert mentoring, provides the just in time professional learning that allows teachers to be supported as they explore the power of the new affordances, and seek to incorporate the IWB technologies into their teaching practice. Technologies can cause anxiety and stress. Peer mentoring offers a support system that can reduce this feeling and offer a clear 
way forward for any teacher to continually increase his/her repertoires and to help students learn. In all the classrooms observed and described here, mentoring made a substantial difference for teachers. It is clear from past experiences, however, that not just any form of mentoring will do. The mentoring described here involved sensitive, non-expert and listening support, and an understanding of the changes in pedagogy that are possible. Externally imposed expert mentoring has rarely worked in the past and is unlikely to do so now.

Furthermore, mentors need to be researchers as well as practitioners. Unless they are able to understand and analyse interactions between the IWB technologies and the teachers and students, they are working in a fog. They need a framework upon which to peg their observations of what is happening with the IWBs in the classroom. In order to observe change, they need an instrument that can help them observe and analyse elements of classroom practice. Either or both of the instruments developed here can act as to fulfil these requirements. There are others (Beauchamp 2004, for example) but the authors have found the two instruments developed here to be particularly useful, and the mentors at the secondary school studied found the HoPS model helped them greatly.

The use of effective analysis instruments is a key part of understanding the rich tapestry of action and interaction in the natural classroom, and must be so if we are to understand the complex relationships between technology and pedagogy. There has been much disquiet about this relationship, including the use of interactive whiteboards. Unlike many UK studies, the researchers in the current study found a positive relationship and complex changes in the way teachers employed strategies as the IWBs were introduced. There were very few lessons in which substitutional use of the boards was observed and many cases where teachers moved to synergistic use involving student development, which produced a weakening of the pedagogical framing to allow student engagement. The only significant difference between this school and most others in the introduction of the technology was the use of peer mentors throughout the year at a high enough time-release level to be thoroughly effective as a teacher support mechanism.

It became very apparent during this study that no one analysis instrument was going to allow a full understanding of the pedagogical changes taking place. This observation indicates that it is dangerous to draw firm conclusions about ICT impact without using a range of tools of analysis. Further research is required to develop analytical instruments that can be used in a wide variety of educational contexts and provide reliable data.

\section{Conclusion}

In this article we reported on our investigations from two projects into aspects of teachers mentoring colleagues. In a year-long project that video recorded secondary school lessons involving IWBs, it appeared that this approach to mentoring teachers in classroom applications of IWBs achieved improved levels of success for all stakeholders. Teachers came to grips with new techniques for interacting with digital material and students, school administrators noted some changes away from a reliance on 'chalk and talk' pedagogy, and students were engaging in IWB-based lessons as well as beginning to produce their own presentations using the IWBs. In another project teachers at several primary schools were also video recorded while teaching 
with an IWB and then interviewed about their perceptions and beliefs concerning the lesson. In both projects the methodologies employed were qualitative, and the subsequent analysis and results suggest that both teachers and learners believed that teaching and learning improved when the IWBs were used.

Unlike in several other studies, the studies reported upon here indicated a positive relationship and complex changes in the pedagogical strategies teachers employed as the IWBs were introduced. Few lessons were observed or video recorded in which the IWB was used as only a substitute for an ordinary board, while there were many cases where teachers weakened the pedagogical framing to allow student engagement and development. The only significant difference between these schools and most others when technology is introduced, was the effective application of peer mentors as a teacher support mechanism. In interviews and surveys teachers continually referred to the peer mentoring support system removing fear of the technology and its unexpected consequences away from the classroom. It was also observed that mentors rapidly assumed that flexible uses and attitudes to pedagogic strategies were as important as skills, and incorporated those attitudes into their work with teachers. The provision of mentors is often seen as an impossibly costly way of doing research. In view of the effectiveness of the mentoring at helping teachers grow professionally compared with the minimal impact of most professional learning models, it is suggested that peer mentoring be financed as one of the few efficient ways of training current teachers, especially when major technological innovations with the power to positively impact on education, appear in our schools.

\section{References}

Beauchamp, G. (2004). Teacher use of the interactive whiteboard in primary schools: Towards an effective transition framework. Technology, Pedagogy and Education, 13(2), 327-348.

Becta (2003). What the research says about interactive whiteboards. Coventry: British Educational Communications and Technology Agency. [viewed 14 Jan 2009].

http: / / partners.becta.org.uk/page_documents / research/wtrs_whiteboards.pdf

Becta (2004). What the research says about ICT and continuing professional development (CPD) for teachers. Coventry: British Educational Communications and Technology Agency. [verified 11 Jun 2010] http: / / research.becta.org.uk/ uploaddir/downloads/page_documents/research/wtrs_cpds.pdf

Bernstein, B. (1990). The structuring of pedagogic discourse, Vol IV: Class, codes and control. London: Routledge.

Clarke, D. (2006). Making connections. Rotterdam: Sense Publishing.

Hall, G. \& Hord, S. (1987). Change in schools: Facilitating the process. Albany, NY: State University of New York Press.

Daresh, J. (2001). Leaders helping leaders: A practical guide to administrative mentoring. Thousand Oaks, CA: Corwin Press.

Feiman-Nemser, S. (2006). Foreword. In J. Shulman \& M. Sato (Eds.), Mentoring teachers towards excellence (pp xi-xiv). San Francisco: Jossey-Bass/Wiley.

Fisher, T., Higgins, C. \& Loveless, A. (2006). Teachers learning with digital technologies. Futurelab Series. [viewed 14 Jan 2009, verified 11 Jun 2010].

http: / / www.futurelab.org.uk/ research/reviews /14_01.htm 
Hay, J. (1995). Transformational mentoring: Creating developmental alliances for changing organizational structures. New York: McGraw-Hill.

Hennessy, S., Deaney, R., Ruthven, K. \& Winterbottom, M. (2007) Pedagogical strategies for using the interactive whiteboard to foster learner participation in school science. Learning, Media and Technology, 32(3), 283-301.

Higgins, S., Beauchamp, G. \& Miller, D. (2007) Reviewing the literature on interactive whiteboards. Learning, Media and Technology, 32(3), 213-225.

Hooper, S. \& Rieber, L. (1995). Teaching with technology. In A. Ornstein (Ed.), Teaching: Theory into practice. Boston, MA: Allyn \& Bacon, 154-170.

Johnson, H. (1997). Mentoring for exceptional performance. Glendale, CA: Griffin Publishing.

Jones A., Mcdougall, A. \& Murnane, J. (2004). What did we think we were doing? Reflections on the history of educational computing in Victoria, Australia. In J. Impagliazzo \& J. Lee (Eds.), History of computing in education (pp. 63-72). Norwell, America: Kluwer Academic Publishers.

Kennewell, S. \& Higgins, S. (2007). Introduction. Learning, Media and Technology, 32(3), 207-212.

Measday, B. (2005). So you've got an interactive whiteboard! Now what? Research Grants Report 2005. Department of Education and Children's Services, South Australia. http: / / www.tsof.edu.au / research/Reports05/ measday.asp [viewed 14 Jan 2009, verified 11 Jun 2010 athttp: / / www.nowwhattraining.com.au/plict.htm]

Miles, M. \& Huberman, A. (1994). Qualitative data analysis: An expanded sourcebook. Thousand Oaks: Sage Publications.

Smith, H. J., Higgins, S., Wall, K. \& Miller, J. (2005). Interactive whiteboards: Boon or bandwagon? A critical review of the literature. Journal of Computer Assisted Learning, 21, 91101.

Tanner, H., Jones, S. Kennewell, S. \& Beauchamp, G. (2005). Interactive whole class teaching and interactive white boards. In P. Clarkson et al. (Eds.), Building connections, theory, research and practice: Proceedings of MERGA 28, Volume 2, pp. 720-727. [verified 11 Jun 2010] http: / / www.merga.net.au/ documents/RP832005.pdf

Vincent, J. \& Jones, A. (2007). Effective teacher professional development to stimulate quality teaching with ICT: A case study of one school and interactive whiteboards. Paper presented at the British Educational Research Association Annual Conference, University of London, 58 September. [verified 11 Jun 2010] http:/ / www.leeds.ac.uk/educol/documents / 165672.htm 
Appendix: Hierarchy of pedagogical stages

(Vincent \& Jones, 2007)

\begin{tabular}{|c|c|c|c|}
\hline \multirow[b]{2}{*}{ Stages } & \multicolumn{3}{|c|}{ Elements of practice } \\
\hline & Teacher skills & ICT usage & $\begin{array}{l}\text { Classroom management } \\
\text { and pedagogy }\end{array}$ \\
\hline Substitution & Little file use. & $\begin{array}{l}\text { Mainly text and } \\
\text { drawing, some learning } \\
\text { objects. }\end{array}$ & $\begin{array}{l}\text { Teacher only; presentation } \\
\text { takes precedence over student } \\
\text { interaction. }\end{array}$ \\
\hline Experimental & $\begin{array}{l}\text { Frequent loading of files. } \\
\text { Pre-prepared lessons. } \\
\text { Some downloading from } \\
\text { Internet. }\end{array}$ & $\begin{array}{l}\text { Wide use of pre- } \\
\text { prepared resources. } \\
\text { Occasional downloads } \\
\text { of resources. Often } \\
\text { many PowerPoint linear } \\
\text { presentations. }\end{array}$ & $\begin{array}{l}\text { Students use the board under } \\
\text { teacher direction: mainly } \\
\text { dragging. Mainly whole class } \\
\text { teaching of lesson topic } \\
\text { Students write and manipulate } \\
\text { text for a defined purpose } \\
\text { under teacher direction. }\end{array}$ \\
\hline Interactional & $\begin{array}{l}\text { Uses stored sequences of } \\
\text { files. } \\
\text { Captures image from } \\
\text { various sources, } \\
\text { including cameras and } \\
\text { non-IWB inputs such as } \\
\text { sound from } \\
\text { microphones, document } \\
\text { cameras etc. Uses } \\
\text { hyperlinks. }\end{array}$ & $\begin{array}{l}\text { Different programs for } \\
\text { different purposes. } \\
\text { Using native } \\
\text { navigation to flip } \\
\text { pages. Internet links for } \\
\text { "if and when" use. } \\
\text { Students build linear } \\
\text { presentations for } \\
\text { sharing with peers. }\end{array}$ & $\begin{array}{l}\text { Frequent student use of teacher } \\
\text { materials needing manip- } \\
\text { ulation (eg changing drawings, } \\
\text { texts etc). Teacher revises and } \\
\text { builds on previous ideas. } \\
\text { Student choices built in. } \\
\text { Expectations of students } \\
\text { include informal and unplan- } \\
\text { ned use of board. Students } \\
\text { encouraged to build linear } \\
\text { presentations (e.g. PowerPoints). }\end{array}$ \\
\hline Synergistic & $\begin{array}{l}\text { Wide range of both } \\
\text { teacher and student } \\
\text { skills, including screen } \\
\text { capture; digitised and } \\
\text { recorded speech; anim- } \\
\text { ations. Students widely } \\
\text { use both native and } \\
\text { other software, include- } \\
\text { ing complex nonlinear } \\
\text { manipulative software } \\
\text { such as graphics mani- } \\
\text { pulations, dynamic } \\
\text { geometry, multimedia, } \\
\text { Excel manipulatable } \\
\text { macros etc. }\end{array}$ & $\begin{array}{l}\text { IWB use embedded } \\
\text { into most lessons } \\
\text { without constraints. } \\
\text { Teacher, with student } \\
\text { help, may create com- } \\
\text { plex learning objects } \\
\text { (such as a game with } \\
\text { embedded curriculum } \\
\text { material). Student build } \\
\text { cooperative texts / } \\
\text { graphics, critical } \\
\text { literacies, cooperative } \\
\text { proof construction } \\
\text { events, etc. }\end{array}$ & $\begin{array}{l}\text { Both teachers and students able } \\
\text { to construct meaning, and } \\
\text { control direction and step } \\
\text { lengths of lessons. Students } \\
\text { able, and encouraged, to } \\
\text { prepare presentations, lessons } \\
\text { and assessments. } \\
\text { Development encouraged of } \\
\text { socially constructed products } \\
\text { (e.g. shared narrative). } \\
\text { Students encouraged to insert } \\
\text { their own structure into the } \\
\text { learning. }\end{array}$ \\
\hline
\end{tabular}

Dr Anthony Jones

ICT in Education and Research, Graduate School of Education

The University of Melbourne, Victoria 3010, Australia

Email: a.jones@unimelb.edu.au

Web: http:/ / www.education.unimelb.edu.au/cgi-bin/public/ staff_profile.cgi?id=7001

Dr John Vincent

ICT in Education and Research, Graduate School of Education

The University of Melbourne, Victoria 3010, Australia

Email: jtv@unimelb.edu.au

Web: http: / / www.education.unimelb.edu.au / cgi-bin/public/staff_profile.cgi?id=11841 